Article

\title{
Feeling Left Out: Underserved Audiences in Science Communication
}

\author{
Christian Humm *, Philipp Schrögel and Annette Leßmöllmann \\ Department for Science Communication, Institute of Technology Futures, Karlsruhe Institute for Technology, \\ 76131 Karlsruhe, Germany; E-Mails: christian.humm@kit.edu (C.H.), philipp.schroegel@kit.edu (P.S.), \\ annette.lessmoellmann@kit.edu (A.L.) \\ * Corresponding author
}

Submitted: 23 September 2019 | Accepted: 23 January 2020 | Published: 18 March 2020

\begin{abstract}
Science communication only reaches certain segments of society. Various underserved audiences are detached from it and feel left out, which is a challenge for democratic societies that build on informed participation in deliberative processes. While only recently researchers and practitioners have addressed the question on the detailed composition of the not reached groups, even less is known about the emotional impact on underserved audiences: feelings and emotions can play an important role in how science communication is received, and "feeling left out" can be an important aspect of exclusion. In this exploratory study, we provide insights from interviews and focus groups with three different underserved audiences in Germany. We found that on the one hand, material exclusion factors such as available infrastructure or financial means as well as specifically attributable factors such as language skills, are influencing the audience composition of science communication. On the other hand, emotional exclusion factors such as fear, habitual distance, and self- as well as outside-perception also play an important role. Therefore, simply addressing material aspects can only be part of establishing more inclusive science communication practices. Rather, being aware of emotions and feelings can serve as a point of leverage for science communication in reaching out to underserved audiences.
\end{abstract}

\section{Keywords}

emotion; exclusion; feelings; focus groups; inclusion; marginalisation; science communication; underserved audiences

\section{Issue}

This article is part of the issue "Emotions and Emotional Appeals in Science Communication" edited by Monika Taddicken (Technische Universität Braunschweig, Germany) and Anne Reif (Technische Universität Braunschweig, Germany).

(C) 2020 by the authors; licensee Cogitatio (Lisbon, Portugal). This article is licensed under a Creative Commons Attribution 4.0 International License (CC BY).

\section{Introduction}

Science communication is more than just imparting scientific knowledge. Emotions play an important role in how messages are received and understood, if the messages get through at all, or if they even cause alienation: "Skepticism of scientific advice was strongly filtered by feelings of distrust and alienation, feelings that were forged by local history, communication mistakes by scientists" (Nisbet \& Scheufele, 2009, p. 1769). This observation was initially described for the (rather unfavourable) reaction of English sheep farmers to communication of scientists following the Chernobyl nuclear accident (Wynne, 1992).
The change from a 'deficit model' understanding of science communication to a dialogue approach-which includes considering context, values, interests, and emotions as part of the communication-is a key aspect for the modern understanding of science communication. Although the deficit model persists (Simis, Madden, Cacciatore, \& Yeo, 2016), current research on science communication and the development of new forms and communication approaches increasingly consider emotional and experiential aspects of science communication beyond the imparting of knowledge: be it the experience of science festivals as informal leisure activities and sources of pleasure (Bultitude \& Sardo, 2012; Davies, 2019) or the specific utilisation of emotions as a tool 
for an effective communication about climate change (Roeser, 2012).

While the role of emotions with a positive connotation as an integral component of science communication is increasingly paid attention to, another crucial aspect received only "a limited amount of research" (Dawson, 2019, p. 24) and awareness so far, despite being named as "one of the most pressing problem[s] in science communication" (Scheufele, 2018, p. 3): The question of which audiences are actually not reached by science communication, why they are not reached, and what role emotional barriers play therein. Answering these questions is highly relevant, considering that being included in science communication is an important prerequisite for participation in modern society, e.g., as a support for evidence-based individual decisions (The Royal Society, 1985 , p. 10), for personal career development (Blanton \& Ikizer, 2019, p. 155), or the informed participation in democratic processes and public debates (Thomas \& Durant, 1987, p. 5).

What is known is that the typical audience for science communication has a high formal education, is already knowledgeable, very interested in science, predominantly white and is affluent (cf. Borgmann, 2005; Gruber, Unterleitner, \& Streicher, 2010; Kennedy, Jensen, \& Verbeke, 2017; Pandya, 2012).

Research and practical approaches in science communication in many cases address only specific aspects of marginalisation, e.g., on gender equality in Science, Technology, Engineering, and Mathematics (STEM) fields (cf. Wang \& Degol, 2017). However, current research in the UK (Archer, Dawson, DeWitt, Seakins, \& Wong, 2015; Dawson, 2019) addresses the broader issue of science communication, education, social exclusion, and marginalisation in a more comprehensive approach, but more focused on the social dynamics and less on the systematisation of underlying drivers and factors. An overarching analysis of exclusion in science communication, based on a systematic literature review, shows that there is a broad range of potential exclusion factors (Schrögel et al., 2018). While some of them, termed 'material exclusion factors' in the following, present concrete barriers (e.g., entrance fees), others ('emotional exclusion factors') include feelings and emotional aspects such as trust, disappointment or fear. For both types of factors, the exclusion can have considerable emotional effects and consequences on excluded groups, who end up with the impression that science is "not for me" (Office of Science and Technology \& Wellcome Trust, 2001, p. 328; see also Koch et al., 2019; Schäfer, Füchslin, Metag, Kristiansen, \& Rauchfleisch, 2018, p. 850):

One of the most difficult feelings to rid oneself of is the emotional turmoil associated with being marginalised by a person or group in the position of power. Feelings of anger and confusion are often followed with those of inferiority. (Granger, 2013)
Tackling this problem requires a profound understanding and respect for the marginalised groups, as otherwise attempts might backfire and become patronising, reinforcing the feeling of exclusion (Granger, 2013).

In this article, we are going to provide a qualitative assessment of the emotional aspects of marginalisation and discrimination in science communication and seek to carve out the roles and relations between the various exclusion factors and their emotional components. The analysis builds on a typology of exclusion factors (Schrögel et al., 2018). The qualitative assessment helps to better understand the shape and intersection of the exclusion factors and their emotional properties and, most importantly, gives access to the voices of the underserved audiences themselves.

Our empirical data is based on focus groups and guided interviews with three demographic groups in Germany chosen as exemplary case studies of underserved audiences in science communication: residents of a marginalised city quarter, students in vocational training (Berufsschüler), and young Muslims with a migration background. The three groups are each characterised by one of the identified exclusion factors, however, it is important to note that they are a statistical group of people with one common attribute, rather than a social group (Vester, 2009, pp. 80-81) with a self-identification as a group. In many other aspects, the members of the groups can be very heterogeneous (Brackertz, 2007, p. 1). Also, the exclusion factor is not to be seen as an attribution of responsibility, nor even as causal for the exclusions. Particularly young Muslims with a migration background are often confronted with discrimination based on external attributions and assumptions, while their religiosity itself might have no impact on the topic (Uslucan, 2014).

Our exploratory analysis of the data seeks to carve out the roles and relations between the various exclusion factors for science communication and their emotional components and provide evidence for the exclusionary effects of feelings and emotional barriers.

\section{Emotions and Exclusion in Science Communication}

\subsection{Emotions in Science Communication}

The role of emotions and feelings in science (communication) has been discussed in regard to several problems-e.g., for effectively communicating climate change (Roeser, 2012; Smith \& Leiserowitz, 2014), for science storytelling (Martinez-Conde \& Macknik, 2017), for the experience of visitors to science centres (Falk \& Gillespie, 2009) and science festivals (Davies, 2019), for the activities and motivation of scientists themselves (Barbalet, 2004) including engaging and communicating with the public (Mizumachi, Matsuda, Kano, Kawakami, \& Kato, 2011).

The definition of emotions and feelings varies in these studies widely. Some use catalogues of discrete 
emotions derived from psychology (Smith \& Leiserowitz, 2014 , p. 940) or apply psychological measuring instruments (Falk \& Gillespie, 2009, p. 113) while others give no definition but list exemplary emotions (Roeser, 2012). This multitude of understandings is not surprising because one can find as much as 92 definitions in the research literature on emotions and feelings (Kleinginna \& Kleinginna, 1981). For this article, we do not expand further on the detailed psychological distinctions between emotions and feelings, but rather use them both in parallel as general concepts of-more or less concreteaffective attitudes towards something.

\subsection{Emotions and Exclusion}

Non-participation in science communication is influenced by a multitude of factors. In the literature on science communication as well as other similar fields-e.g., health communication, political participation or adult education-one can identify more than 30 exclusion factors. To provide a more structured overview on the range of factors, we previously proposed a typology (Schrögel et al., 2018) which categorises exclusion factors into three layers: individual factors (e.g., language, reading, and writing skills); social factors (e.g., regional affiliation, disabilities); and structural factors (e.g., location, available support, and services). The factors reach from 'lack of interest' to more complex structures like science literacy or habitus (Bourdieu, 1982). Also, they are often interwoven, which impedes an isolated examination.

However, in the already scarce research literature on exclusion in science communication, the role of emotions and feelings for non-participation remains largely unexamined. The effect of 'feeling left out' has been described for ethnic minorities and their participation in everyday science learning practices. For them, "emotional labour, the extra work required to 'fit' and the discomfort of not 'fitting"' (Dawson, 2019, p. 91) leads to exclusion, because "walking into a science museum or similar everyday science learning practice carries a significant emotional burden, a burden that plays into dispositions and tastes, as a preference not to be in such spaces" (Dawson, 2019, p. 103). This "emotional work" (Hochschild, 1979) can contribute to a feeling of 'not for me' in marginalised groups.

The engagement with science in schools seems to be patterned by the amount of science capital students command. The concept builds on Bourdieu's capital theory and comprises "science-related forms of social capital (e.g., contacts, social networks, knowing people who work in STEM...) and cultural capital (qualifications, enduring habits/dispositions, scientific literacy...)" (Archer, DeWitt, \& Willis, 2014, p. 5). The amount students command correlates with "whether they feel that others see them as a 'science person"' (Archer et al., 2015, p. 941). Students with low science capital "lack confidence in their science identities and feel that others do not see them as 'science people"' (Archer et al., 2015, p. 941).
The importance of emotions and feelings for social exclusion and (non-)participation has been described for other areas as well. The "emotional effect of family poverty" has been listed as one of five barriers hindering participation in adult education and the "level of emotional support a person receives can also affect the likelihood that she or he will engage in literacy programs" (Flynn, Brown, Johnson, \& Rodger, 2011, p. 44). For students with a socio-economically disadvantaged background, with disabilities or from ethnic minorities, "negative attitudes towards their study from friends, parents and partners" (Bamber \& Tett, 2000, p. 65) and their own unfavourable school experiences are additional burdens besides more material problems, like lacking financial resources. Emotions can also influence political participation, with anger showing a positive effect and anxiety a negative effect with regard to participation in elections (Valentino, Brader, Groenendyk, Gregorowicz, \& Hutchings, 2011; Valentino, Gregorowicz, \& Groenendyk, 2009).

The role of "emotional oppression" (Watermeyer, 2013 , p. 152) has been described for the social exclusion of people with disabilities, where these emotional barriers intersect with "material barriers" (Watermeyer, 2013, p. 44), like poverty. We adopt this distinction between emotional and material barriers to broadly categorise the aforementioned exclusion factors in science communication. Furthermore, we also subsume specific, but not necessarily tangible, factors like language skills under material factors, besides physical factors like accessibility or financial resources. Subsequently, we distinguish between two types of exclusion factors: those on the level of emotions and feelings on the one hand, and material factors on the other. The former includes, among other things, the feeling of not being addressed by offerings or the fear of embarrassment by a lack of knowledge. The latter can be for example time constraints because of shift work or a lack of money to afford entrance fees.

\section{Methods and Data Basis}

The data presented in the following is based on three demographic groups: residents of a marginalised city quarter in Berlin-Spandau, students in vocational training in Karlsruhe, and young Muslims with a migration background from Berlin. The groups have each been chosen as three exemplary case studies representing often-by science communication - not reached segments of society. The aim of the focus groups and interviews (for an overview, see Table 1, or the Supplementary Material for more details) was to learn more about the everyday lives of the groups, their attitudes towards science and science communication, their (non-)participation therein and the reasons behind it. Besides members of the groups, we also surveyed various other actors who can be described as socially engaged persons or in short engaged person-for example, community representatives, social workers, teachers and stakeholders. These 
engaged persons have a strong connection and privileged access to the communities. They were included for two reasons: First, as a pragmatic solution to the difficulty to access the communities; and secondly to provide a broader and more reflected perspective than interviews with 'isolated' individuals could.

Socio-economically disadvantaged and marginalised urban communities often live in certain city quarters, although social-spatial theories describe more complex theories for marginalisation overall (Otto, Ziegler, \& Landhäußer, 2006). These quarters are often characterised by an above-average unemployment rate, lower formal educational backgrounds, and less scientific, educational and cultural infrastructure. Due to this lack of access points contact with science communication-if not mediated via mass media-is limited. For our study, we chose the formally defined district development areas Falkenhagener Feld East and West in Berlin-Spandau. In these two areas, $45,6 \%$ to $49 \%$ of residents have a migration background (the average for Berlin is 32\%), the percentage of residents receiving transfer income is around $33 \%$ (the average for Berlin is $16,59 \%$ ), the unemployment rate is at around $7 \%$ (the average for Berlin is $4,3 \%$ ), the percentage of children in poverty lies at around $55 \%$ while the average for Berlin is $29,8 \%$ (GeSop $\mathrm{mbH}, 2019 \mathrm{a}, 2019 \mathrm{~b})$.

We conducted one focus group with engaged persons and semi-structured street interviews with residents. The engaged persons included a person from neighbourhood management (Quartiersmanagement), representatives of various informal learning initiatives and a volunteer social worker. The street interviews were

Table 1. Overview of the data basis.

\begin{tabular}{|c|c|c|c|c|}
\hline Group & Method & Date & Demographics & Abbreviation \\
\hline Vocational Students & $\begin{array}{l}\text { Focus group } \\
(n=10)\end{array}$ & $25 / 09 / 2018$ & $\begin{array}{l}\text { age: } 19-25 \\
\text { mean age: } 20.7 \\
\text { men: } 8 \\
\text { women: } 2 \\
\text { engaged persons: } 3 \\
\text { students: } 7\end{array}$ & Voc_F-1 \\
\hline Vocational Students & $\begin{array}{l}\text { Focus group } \\
(n=17)\end{array}$ & $06 / 11 / 2018$ & $\begin{array}{l}\text { age: } 18-25 \\
\text { mean age: } 20.1 \\
\text { all male } \\
\text { engaged persons: } 0\end{array}$ & Voc_F-2 \\
\hline $\begin{array}{l}\text { Marginalised City } \\
\text { Quarter }\end{array}$ & $\begin{array}{l}\text { Focus group } \\
(n=5)\end{array}$ & $26 / 07 / 2018$ & $\begin{array}{l}\text { men: } 1 \\
\text { women: } 4 \\
\text { engaged persons: } 5\end{array}$ & Mar_F \\
\hline $\begin{array}{l}\text { Marginalised City } \\
\text { Quarter }\end{array}$ & $\begin{array}{l}\text { Guided interviews } \\
(n=18)\end{array}$ & 08/09/2018-15/09/2018 & $\begin{array}{l}\text { age: } 16-55 \\
\text { mean age: } 33.1 \\
\text { men: } 6 \\
\text { women: } 12 \\
\text { engaged persons: } 0\end{array}$ & Mar_I-1...Mar_I-15 \\
\hline $\begin{array}{l}\text { Young Muslims with a } \\
\text { Migration Background }\end{array}$ & $\begin{array}{l}\text { Focus group } \\
(n=10)\end{array}$ & 09/04/2019 & $\begin{array}{l}\text { age: } 19-25 \\
\text { mean age: } 21.4 \\
\text { men: } 9 \\
\text { diverse: } 1 \\
\text { engaged persons: } 0\end{array}$ & You_F-1 \\
\hline $\begin{array}{l}\text { Young Muslims with a } \\
\text { Migration Background }\end{array}$ & $\begin{array}{l}\text { Focus group } \\
(n=6)\end{array}$ & 27/04/2019 & $\begin{array}{l}\text { age: } 21-23 \\
\text { mean age: } 22.2 \\
\text { men: } 1 \\
\text { women: } 3 \\
\text { diverse: } 2 \\
\text { engaged persons: } 0\end{array}$ & You_F-2 \\
\hline $\begin{array}{l}\text { Young Muslims with a } \\
\text { Migration Background }\end{array}$ & $\begin{array}{l}\text { Guided interviews } \\
(n=10)\end{array}$ & 16/01/2019-28/02/2019 & $\begin{array}{l}\text { men: } 5 \\
\text { women: } 5 \\
\text { engaged persons: } 10\end{array}$ & You_I-1...You_I-7 \\
\hline
\end{tabular}

Notes: Demographics where available. The age of the teachers and the expert in the first vocational student's focus groups is not known. The students of the vocational school are typically men (more than $90 \%$ of the pupils are male). 
a substitute for a focus group with residents because it turned out to be impossible to organise a focus group with enough participants. All interviews were conducted during several days in September 2018 with passers-by at several locations within the quarter, i.e., at a central square, during a street festival, and a garage sale. The interviews lasted about five to ten minutes each.

Students in vocational training are often not considered in public debates on education (Blaß \& Himmelrath, 2016). They are usually neglected by science communication, as they are neither addressed by science communication focusing on high school students as potential future university students nor are they addressed by adult science communication. We conducted two focus groups with students in vocational training from a school for plumbing and heating in the city of Karlsruhe. The first focus group consisted of a mixed group of committed students and engaged persons (two teachers and one external expert-a scientist researching political participation of vocational students in another German city). The second focus group was made up of seventeen students attending the same class.

Religious beliefs can influence actual or perceived attitudes towards science and science communication (Hagay et al., 2013). Furthermore, (externally perceived) religious affiliation can be a potential target to discriminate against, which is especially true for Muslims in Europe. In this case, religion is often only a proxy and discrimination is targeting actual or perceived migration backgrounds (European Union, 2017). That such experiences of discrimination can negatively affect participation in science communication has been shown for the UK (Dawson, 2019). This phenomenon has been reported for young Muslim people in Germany independently of their cultural or family background (El-Mafaalani \& Toprak, 2011).

We conducted two focus groups with young Muslims with a migration background in Berlin. The focus groups were organised together with two non-governmental organisations that work together with Muslim youths with a migration background. This access to the field was chosen because both organisations are not addressing exclusively certain ethnical backgrounds, e.g., Turkish or Islamic faiths (e.g., Sunnites). Of the 16 participants in both focus groups three were born outside of Germany, eight reported that both parents were born outside of Germany and four stated that one of their parents was born abroad. Only one participant stated that he/she and her/his parents were born in Germany. Thus, the overall majority of the participants had a migration background in a wider sense (Kroh \& Fetz, 2016). Additionally, guided interviews with ten engaged persons from seven organisations and initiatives were conducted.

The abbreviations used to label quotes from the data follow the scheme group, data collection method ( $F$ for focus group, I for guided interview) and the interview or focus group number. Additionally, if the person quoted is an engaged person this is marked by the suffix 'engaged.'
Video, or where not possible audio, recordings were made of all interviews and focus groups. The recordings were then transcribed and analysed according to qualitative content analysis (Mayring, 2010). The categories used to code the transcripts were, in the beginning, deductively based on 31 exclusion factors identified in a literature review (Schrögel et al., 2018, p. 57). The categories were then inductively further adapted and refined to reflect the new perspective of the group's reported exclusion factors found in the material (Kuckartz, 2016, p. 47). Subsequently, these factors were categorised as either emotional or non-emotional, i.e., material.

During the analysis, it became clear that emotions and feelings concerning science communication cannot be easily separated from those associated with science and the education system in the broader sense, as they are often interwoven.

\section{Results}

One commonality between all groups was that they seldom consume science communication at all. If they do, then mostly by consuming TV formats, like documentaries or science shows, or by using online formats, like videos on YouTube or Wikipedia. This observation fits in with a qualitative media diary study on science communication audiences in Switzerland (Koch et al., 2019 , p. 13) as well as with the results of the survey Wissenschaftsbarometer for Germany (Wissenschaft im Dialog \& Kantar Emnid, 2018, pp. 9-12). In all three groups, some participants reported that they had visited museums in the past. However, almost all of these visits did take place as part of compulsory school activities. Science communication via print media played virtually no role in the answers.

However, the relevance of exclusion factors varied partly between the groups. While most found factors were relevant for all groups-i.e., financial resources, fear, frustration, and insecurity, emotional and habitual distance and self-perception and outside-perceptionothers only affected a part of the groups, i.e., lack of (local) offerings and infrastructure, language, and time resources (see Table 2).

Exclusion factors found in the data that are identical to the typology are 'financial resources,' 'language,' and 'time resources.' The name of the factor 'fear' from the previous typology has been changed to 'fear, frustration, insecurity' to better reflect its scope. The 'lack of (local) offerings and infrastructure' cannot be found in the typology but featured prominently in the material. Also missing in the typology are the factors 'emotional and habitual distance' and 'self-perception and outside-perception.' They could be both subsumed under the relatively wide exclusion factor 'missing familiarity/habitus/science capital' in the original typology. However, such subsumption would not adequately represent the specific characteristics of the exclusion mechanisms found in our data and might indicate that the fac- 
Table 2. Overview of the exclusion factors found in the data.

\begin{tabular}{lllll}
\hline Type of Factor & Identified Group- & Residents in a \\
& Reported Exclusion & Mactors & $\begin{array}{l}\text { Vocational } \\
\text { Marginalised City } \\
\text { Quarter }\end{array}$ & $\begin{array}{l}\text { Young Muslims } \\
\text { with a Migration } \\
\text { Background }\end{array}$ \\
\hline Material Exclusion & Lack of (local) Offerings and Infrastructure & $\mathrm{X}$ & $\mathrm{X}$ & - \\
Factors & Financial Resources & $\mathrm{X}$ & $\mathrm{X}$ & $\mathrm{X}$ \\
& Language & - & - & $\mathrm{X}$ \\
& Time Resources & - & $\mathrm{X}$ & $\mathrm{X}$ \\
Emotional Exclusion & Fear, Frustration, Insecurity & $\mathrm{X}$ & $\mathrm{X}$ & $\mathrm{X}$ \\
Factors & Emotional and Habitual Distance & $\mathrm{X}$ & $\mathrm{X}$ & $\mathrm{X}$ \\
& Self-Perception and Outside Perception & $\mathrm{X}$ & $\mathrm{X}$ & $\mathrm{X}$
\end{tabular}

Notes: There are several explanations for not finding the exclusion factors of language, lack of (local) offering and infrastructure, and time resources in all groups. Maybe the groups are not, or less, affected by them, or they did not mention them because of recruiting and interview effects.

tor in the typology is too broad to be a suitable category for analysis.

\subsection{Material Exclusion Factors}

The identified material exclusion factors comprise concrete tangible resources such as infrastructure or financial means as well as specifically attributable factors such as language skills.

\subsubsection{Lack of (Local) Offerings and Infrastructure}

One exclusion factor only brought forward in the city quarter was the lack of local science communication opportunities:

Interviewer: Did you attend scientific events in Spandau? Is there anything around here where you would like to go to?

Resident: No, unfortunately, there is nothing here. (Mar_I-6)

This impression was stated by engaged persons too: "So, we have a lot of social institutions in the area [in Spandau], we don't have a university, we don't have a university of applied sciences. That's what we are lacking" (engaged person 4, Mar_F_Engaged).

At first, this might be surprising because Berlin as the German capital is home to a multitude of scientific institutions engaging with the public. However, in a city quarter with a high level of unemployment and a low average income people might lack the financial means to afford mobility beyond the limits of their Kiez (how Berliners call their neighbourhoods): "I think this has a lot to do with the personal economic situation. Whether I can afford a car or a bus ticket, BVG [public transportation in Berlin]" (engaged person 4, Mar_F_Engaged).

In a broader sense, a lack of opportunities was also articulated as an exclusion factor by the vocational students. In their case, the locality of a science event is not as much of a problem, but the (perceived) disinterest from science communicators in reaching out to them. This, in turn, creates a feeling of 'not for us':

Expert 1: I often heard something like you [directed to the vocational students present in the focus group] have said...that you never really came into contact with [science communication]. But it was also strongly mentioned that they have the feeling that they are not welcome there [at science organisations] at all. (Voc_F-1_Engaged)

Vocational Student 6: People from the university could maybe more often go to middle schools [Hauptschulen] and perhaps introduce something or cooperate with them. But one doesn't notice anything like that. (Voc_F-1)

\subsubsection{Financial Resources}

Besides the lack of financial resources for transportation to get to science communication formats mentioned above, the aspect of money was also brought forward in one of the focus groups with young Muslims with a migration background as a reason for not going to museums:

Well, it's again a question of access. The Pergamon Museum [in Berlin], I think, costs 12 euros to enter....And when my parents came to visit me, we were lucky that there was a day with free admission, because otherwise I could not have brought them in. And these are people who are interested in it, but...you pay 50-60 euros if you go somewhere together. (young person 1, You_F-2)

The difficult economic situation also leads to the problem that-according to the engaged personsinhabitants of the marginalised city quarter are preoccupied with their own lives and imminent challenges. Together with the isolation within their quarter, this seems to lead to a kind of "tunnel vision that most people 
have," as one engaged person put it (Mar_F_Engaged), where science (communication) plays no role.

Interestingly, money is a concern not only featured in relation to entrance fees or transportation costs, but it also came up concerning going to university; among the young Muslims with a migration background:

Another problem is, although we came here [to Germany] with the dream to become a scientist or something like that, there is simply a lack of resources. Even if you do your Bachelor or Master studies, there is family pressure to earn money. (young person 4, You_F-2)

As well as among the vocational students:

Moderator 2: Is there anyone else...who has thought about [studying]?

Vocational Student 7: The dream is shattered anyway when you realise that the money is missing. (Voc_F-2)

\subsubsection{Language}

Language as a barrier for participating in science communication appeared in all three groups, though in three different ways. For non-German speakers, monolingual science communication can function as a barrier, this was mentioned for the city quarter and by the young Muslims with a migration background. For example, when asked what is needed in science communication one participant stated: "But what is also very important: more interpreting services. There are so many languages...that are hardly represented. And today it is simply not enough anymore-if you're really, really lucky-to have a Turkish interpreter [at an event]" (young person 4, You_F-2).

While language in this context functions as an exclusion factor because it impedes understanding, the usage of a certain language can also exclude people by creating a habitual distance as we show in Section 4.2.2.

\subsubsection{Time Resources}

For the vocational students, a big barrier was the time that they were willing or able to spend on science communication as part of their leisure time. Between going to their school and working in their firms they simply do not seem to find time to attend science communication events:

There are people who work from Monday to Friday and then also work on Saturdays, too, so that they somehow make ends meet. Then only Sunday remains. That's just far too little time to recover or do anything in general. (vocational student 7, Voc_F-1)

One interpretation of this statement could also be that rare spare time to spend for leisure time is preferably devoted to activities that guarantee a relaxed or confident surrounding, features which a science communication might not offer-due to exclusion factors noted above, like the language used by communicators and the audience.

Available leisure time can also correlate with socioeconomic background: "Maybe people with a migration background are more likely to do shift work and therefore don't have the time for it, and the cause is not a lack of interest due to their migration background" (young person 6, You_F-1).

\subsection{Emotional Exclusion Factors}

The emotional factors comprise a less narrowly definable set of feelings and emotional reactions to marginalisation.

\subsubsection{Fear, Frustration, and Insecurity}

Not being familiar with science communication and its institutions can evoke feelings of fear and insecurity and thus make people refrain from taking part in it. The following excerpt from the focus groups with engaged persons in the marginalised city quarter illustrates how this kind of insecurity is passed on from parents to children. Furthermore, it shows how science communication is interwoven with school education:

[Parents] have the problem that they do not know these areas. So, university, graduating from high school, going to a museum. The parents don't know that. That's why they don't pass it on to their children...the parents just feel insecure.

It must also be said that many parents, especially those with a migration background, have perhaps attended the fifth grade at most and the school is above all a place of failure [for them]. (engaged person 3, Mar_F_Engaged)

The bad experiences and frustration with the school system lead not only to negative feelings towards schoolsas 'places of failure' - but also 'spill-over' to other places associated with education, like museums or libraries, which can also be places of science communication, and lead to negative emotions or disinterest towards science itself:

Well, I've never heard the word science from the mouth of a teenager before. But, so, if you associate science with learning. Well, learning has rather negative connotations....And if you deduce from the way we set our pedagogical goals about how learning is connoted, then I would say, [it is] not a term with a positive connotation. Neither is education. (engaged person 1, Mar_F_Engaged) 
Furthermore, 'higher' educational aspirations of the children are met with scepticism and resistance: "The [child] had one, a recommendation for high school, but the mother said, 'yes, you now go to the ISS [Integrierte Sekundarschule; Integrated secondary school]'..., 'don't do your high school diploma [Abitur], you can't do that anyway" (engaged person 2, Mar_F_Engaged).

Contributing to this disconnection with the science system is a lack of scientists from underserved communities as role models: "Simply this role model thing. I believe this is a very important point. When, in a certain group, nobody shares any [science] experience with me, just because there is nobody, then I don't have any relation to it" (young person 5, You_F-2).

Fear and insecurity were not only reported in the marginalised city quarter but also in the Muslim group. One participant expressed his fear of being embarrassed because as a non-native speaker he might not understand everything. This shows that even material barriers-such as language skills-have an emotional component:

I don't understand everything because it's in German...that's why I'm afraid to go there [to science communication events], because I think people may ask me questions. And then I'm like "I don't know, I don't know what I am doing here." (young person 6, You_F-2)

This anxiety of failing or being embarrassed was also voiced by the vocational students, however not so prominently:

If you go to a public talk, you'd rather ask the questions towards the end, and if you sit there in the talk you couldn't ask a question if you didn't understand something, then you don't ask at the end either. Then it comes across like this, yes, the middle school [Hauptschule] pupil didn't understand anything again. (young person 6, Voc_F-)

\subsubsection{Emotional and Habitual Distance}

For the young Muslims with a migration background as well, as for the vocational students, one reason for their distance towards science and science communication was that they did not feel that they were being taken seriously. For example, one participant reported that she feels not being taken seriously at university (You_F-2), while-according to the invited external expert-vocational students often "[have] the feeling that they are never asked or consulted" (Voc_F-1_Engaged).

One point where the habitual distance became visible for the young Muslims with a migration background was in the used language in science communication. In this case, language serves as a signifier of habitual distance by being elitist, signalling the belonging to a certain social class. This was brought up several times:
Now for science slams. Well, I was at two [of them], for example. I just found...both super classist [as an expression of classism]...[in] one [slam where] maybe four people have performed something and three out of four just somehow made fun of...ghetto language and ghetto slang and things like that in a bourgeois manner...and that was just super exhausting because...there are suburban children...and then they just start like "yes, I was in the ghetto" and by that they mean [Berlin] Kreuzberg or something. (young person 2, You_F-2)

Such emotional and habitual distance means that participating in science communication activities can require additional emotional labour. This was observed for ethnical minoritized groups in England (Dawson, 2019, pp. 91, 103) and it also was an important point for participants in our focus groups of young Muslims with a migration background:

You are never allowed to show feelings, because then you are entering an emotional level, being unscientific. I think the problem is that science-that is to say what we understand by science-is a very Western concept, which is incompatible, for example, with many of our cultural experiences or the way in which we discuss things at home, but one has to adopt a mentality in order to be taken seriously [in science]. (young person 4, You_F-2)

Thus, one could argue that while "[e]ngagement with science, of any kind, may demand...emotion work" (Davies, 2019 , p. 19), this is even more laborious for excluded audiences - to the point of being too laborious to participate. Notably, such direct references to emotional work as a factor hindering the participation in science communication was not mentioned in the city quarter or among the vocational students.

\subsubsection{Self-Perception and Outside Perception}

Instead of seeing themselves as a "science person" (Archer et al., 2015, p. 932), marginalised groups take on an identity where science-and science communication-is 'not for me.' The following answer to the question of why the person does not engage with science communication illustrates this for the residents of the city quarter 'Falkenhagener Feld': “I've never been a person really interested in science. I've always been the guy for physical work" (resident, Mar_I-7).

The same observation could be made for the vocational students:

Well, I guess you often think about it, shit, these are smart people and maybe I'm not the smartest here... (vocational student 7, Voc_F-1) 
We are just craftsmen; we have to see what we do. (vocational student 6, Voc_F-1)

Therein, their self-reception is similar to what has been described for other excluded audiences (Dawson, 2019, p. 71). The young Muslims with a migration background, additionally, remark that it is not only a matter of selfperception but also of being recognised by others as a 'science person': “We're not even considered scientists. So, when one talks about a person with a migration background, or, let's call a spade a spade, when one talks about me...a Turk...one doesn't think about science" (young person 1, You_F-2).

This becomes apparent for them, for example, through schoolteachers recommending not to go to university, because of their migration background or social class, or when they observe a lack of diversity at German universities. Because they experience science as 'white,' they associate it with being elitist and hence they feel excluded. This was not only mentioned by the young persons themselves, but also by one engaged person from the group (You_l-1_Engaged). Feeling uncomfortable has real consequences for the participants in discouraging them and diverting them from science:

And I think it also does a lot of unconscious things... when you know you wouldn't be seen as a scientist, then it does a lot of unconscious things to you. I think to myself: 'I won't do it at all, I won't be able to do it.' That does so much to me. (young person 6, You_F-2)

Of course, this is directed more broadly towards participation in science in general than just only towards participation in science communication. However, as participants in all three groups often did not clearly distinguish between taking part in and conducting science and science communication, one can assume that there is a spillover effect between the two.

\section{Conclusion}

When interpreting our results, one has to keep the limitations in mind. The data is based on three demographic groups and a limited number of interviews and focus groups. As both methods used to collect data-guided interviews and focus groups-rely on the self-disclosure of participants, their answers might be affected by cognitive and social effects, like question order and wording (Scholl, 2018) or-especially for stigmatised and minoritized groups-stereotype threat (Spencer, Logel, \& Davies, 2016) and, thus, social desirability. However, our findings are in line with previous findings with regard to access to and exclusion from science and science communication (Archer et al., 2015; Davies, 2019; Dawson, 2019) and the data can, therefore, be assumed to be exemplary for other not reached groups in science communication. To corroborate the findings and provide more robust insights, it would be fruitful to collect more data for other typically not reached groups as well and from further members and engaged persons of the three groups examined here. This would also allow for the development of a comprehensive typology of emotional exclusion factors and the emotional effects of exclusion in science communication.

There are likely other reasons why people are (feeling) excluded from science communication. The fact that we identify more exclusion factors in the literature is an indicator thereof (Schrögel et al., 2018). We assume at least three reasons for not finding more or other of these factors in the data. First, our exploratory approach might only have delivered the most relevant factors for the surveyed persons. To capture this relevance criterion by the groups themselves we did not ask them a checklist of all exclusion factors from the literature review. It is conceivable that although there are factors that apply to the groups, these are not relevant or conscious enough to be mentioned. Second, the factors not mentioned might not affect the groups. Third, they might not have been mentioned because of the effects of the methods used.

Furthermore, the study is not based on an in-depth psychological model of emotions and feelings and does not develop a detailed classification of these notions. This aspect lies beyond the scope of this work, which is meant to provide an overview of the emotional component of marginalisation in science communication and showcase the width of effects.

Nevertheless, several conclusions can be drawn from the presented data. First, to broaden the diversity of science communication audiences it is not enough to just tackle the material barriers, e.g., reduce entrance fees. The experience with removing entrance fees to some large museums in the UK illustrates this:

While the number of people visiting these 'free' museums increased significantly, it turned out that this was simply because more of the same kinds of people (white, middle-class, urban families) visited these museums and repeated their visits more often....In other words, getting rid of upfront entrance costs did little to change the visitor profile to these museums. The economics of participation run deeper than entry costs and are about far more than socio-economic position or class background. (Dawson, 2019, p. 95)

Instead, we argue from our data that emotional factors play a crucial role as well in excluding groups from science communication-possibly making the difference between inclusion in or exclusion of science communication. Thus, these factors have to be considered and addressed if science communication shall reach broader and more diverse audiences.

Second, emotional exclusion factors in science communication cannot be easily distinguished from emotional experiences and barriers in the education system and science in general. They often intersect, especially 
bad experiences in the school system seem to have a lasting impact on participation in science communication. This has also been described by Dawson (2019, p. 71):

Science education research has found that school science has a widespread influence on how people see science, not least in the seemingly inescapable framing of science in general in terms of school subjects, namely, biology, chemistry and physics (Osborne, Simon, \& Collins, 2003).

These experiences "are lasting and salient features of how people relate (or not) to everyday science learning" (Dawson, 2019, p. 68) and, thus, to what we call science communication. Consequently, it is hardly surprising that in our data people often did not distinguish between science communication, science and school education, but mixed it up. For many people, the education system is still the first point of contact with science and science communication (being it in school lessons or through school visits to museums, for example). Furthermore, the emotions towards science and the feeling of being left out seem to get 'passed on' from parents to their children. While this observation needs further investigation, it would fit in with the relation between the education of children and their social background, for example, as reported for Germany (Kuhlmann, 2008).

Third, these emotional barriers can only get successfully tackled by long-term activities building trusting relations because the barriers' causes lie in long-term negative experiences, as Dawson (2019) shows and our data support, with discrimination and neglect by science communication practices. Therefore, it is important not to understand these barriers as deficits of the not reached groups, but as factors for which science communication is responsible. One of our participants verbalised this 'deficit look' as follows:

When I now look at Muslims in Germany in general, I find that the view of this group of people is rather deficient....I don't see much of this look: "Hey, how can they feel better, how can they be happier with one thing," but rather so: "How can we offer them something so that they don't harm society or so that this group doesn't endanger another group." (young person 1, You_F-1)

However, emotions and feelings can be a starting point for successful science communication with nonreached groups, as engaged persons in our focus groups pointed out:

It is also very important to take the person seriously. So that you also give them the feeling "you are an individual, your opinion has a value, you can achieve something with that opinion" and if the community or that person...if they notice "okay, they take me really seriously and the offer is also specifically for me or I fit to this offer" then this is embraced. (engaged person 2, Mar_F)

To give a very concrete example: One of our engaged persons reported that the participants of a visit to the Museum for Islamic Art Berlin "felt highly esteemed" (You_l-3) because the museum's guides were also Arabicspeaking Syrians. This emotional access can also provide the basis to build trust towards scientists: "If you have a person who knows what he or she's talking about and can convey things in an interesting way, then that's respected and acknowledged, and that's not through the title, expert XY, but through an emotional approach" (engaged person 3, Mar_F).

Such an 'emotional approach' requires changing established science communication practices and starts with listening to underserved audiences and taking their (emotional) needs seriously. This includes measures to reduce the (emotional) distance, e.g., through the use of humour or by giving up the display of an academic habitus, as well as to critically reflect and change practices that might have-intentionally or unintentionallya discriminatory effect on people. Especially regarding the needed emotional labour to participate, communicators should "ask the question: what are we asking of people? And to what extent will this be experienced as laborious?" (Davies, 2019, p. 19).

Not only could the science communication practice profit from addressing material and emotional exclusion factors, but also research should focus more on the role of factors-especially emotional-in fostering or hindering participation in science communication. To broaden participation and engagement, we have to understand what leads to exclusion on both a material and an emotional level in the first place.

In conclusion, we hope that this study can serve to inform science communication researchers as well as practitioners and contribute to improving equity and inclusiveness in science communication.

\section{Acknowledgments}

We would like to thank the participants in our focus groups as well as our interview partners for their cooperation and for giving consent to the publication of pseudonymised verbatim quotes. Also, we would like to thank our colleagues at Wissenschaft im Dialog as well as the reviewers and editors for the fruitful discussions and remarks, as well as our student assistants Eva Pflästerer and Luisa Schnepf for their help in collecting and preparing the data and proofreading the manuscript. This research was conducted as part of the project 'Wissenschaft für alle' ['Science for all'] and funded by the Robert Bosch Foundation.

\section{Conflict of Interests}

The authors declare no conflict of interests. 


\section{Supplementary Material}

Supplementary material for this article is available online in the format provided by the authors (unedited).

\section{References}

Archer, L., Dawson, E., DeWitt, J., Seakins, A., \& Wong, B. (2015). "Science capital": A conceptual, methodological, and empirical argument for extending bourdieusian notions of capital beyond the arts. Journal of Research in Science Teaching, 52(7), 922-948. https:// doi.org/10.1002/tea.21227

Archer, L., DeWitt, J., \& Willis, B. (2014). Adolescent boys' science aspirations: Masculinity, capital, and power. Journal of Research in Science Teaching, 51(1), 1-30. https://doi.org/10.1002/tea.21122

Bamber, J., \& Tett, L. (2000). Transforming the learning experiences of non-traditional students: A perspective from higher education. Studies in Continuing Education, 22(1), 57-75. https://doi.org/10.1080/ 713695715

Barbalet, J. (2004). Consciousness, emotions, and science. In J. H. Turner (Ed.), Theory and research on human emotions (Vol. 21, pp. 245-272). Bingley: Emerald Group Publishing. https://doi.org/10.1016/ S0882-6145(04)21010-4

Blanton, H., \& Ikizer, E. G. (2019). Elegant science narratives and unintended influences: An agenda for the science of science communication-Unintended influence. Social Issues and Policy Review, 13(1), 154-181. https://doi.org/10.1111/sipr.12055

Blaß, K., \& Himmelrath, A. (2016). Berufsschulen auf dem Abstellgleis: Wie wir unser Ausbildungssystem retten können [Vocational schools on the sidelines: How we can save our vocational training system]. Hamburg: Edition Körber-Stiftung.

Borgmann, M. (2005). Evaluation Synthesis zu Angeboten der Wissenschaftskommunikation im Rahmen der Evaluation des 'Jahrs der Technik 2004' [Evaluation synthesis on science communication offers within the evaluation of the 'year of technology 2004']. Cologne: Univation. https://doi.org/10.2314/ GBV:506379280

Bourdieu, P. (1982). Die feinen Unterschiede. Kritik der gesellschaftlichen Urteilskraft [Distinction: A social critique of the judgement of taste] (26th ed.; B. Schwibs \& A. Russer, Trans.). Frankfurt: Suhrkamp.

Brackertz, N. (2007). Who is hard to reach and why? (ISR Working Paper). Hawthorn: Swinburne Institute for Social Research. Retrieved from http://hdl.handle. net/1959.3/23213

Bultitude, K., \& Sardo, A. M. (2012). Leisure and pleasure: Science events in unusual locations. International Journal of Science Education, 34(18), 2775-2795. https://doi.org/10.1080/09500693.2012.664293

Davies, S. R. (2019). Science communication as emotion work: Negotiating curiosity and wonder at a science festival. Science as Culture, 28(4), 538-561. https:// doi.org/10.1080/09505431.2019.1597035

Dawson, E. (2019). Equity, exclusion \& everyday science learning: The experiences of minoritised groups. New York, NY: Routledge.

El-Mafaalani, A., \& Toprak, A. (2011). Muslimische Kinder und Jugendliche in Deutschland: LebensweltenDenkmuster-Herausforderungen [Muslim children and young people in Germany: Life worlds-Patterns of thought-Challenges.]. Sankt Augustin: Konrad Adenauer Stiftung.

European Union. (2017). Second European Union minorities and discrimination survey: Muslims-Selected findings. Luxembourg: European Union.

Falk, J. H., \& Gillespie, K. L. (2009). Investigating the role of emotion in science center visitor learning. Visitor Studies, 12(2), 112-132. https://doi.org/10.1080/ 10645570903203414

Flynn, S., Brown, J., Johnson, A., \& Rodger, S. (2011). Barriers to education for the marginalized adult learner. Alberta Journal of Educational Research, 57(1), 43-58.

GeSop mbH. (2019a). IHEK 2019-2022. Integriertes Handlungs-und Entwicklungskonzept Quartiersmanagement Falkenhagener Feld Ost BerlinSpandau [Integrated action and development concept neighbourhood management Falkenhagener Feld East Berlin-Spandau]. Berlin: GeSop mbH. Retrieved from https://falkenhagener-feld-ost.de/ffost-wordpress/wp-content/uploads/2019/08/IHEKFF-Ost-2019-2022-nB.pdf

GeSop mbH. (2019b). IHEK 2019-2022. Integriertes Handlungs-und Entwicklungskonzept Quartiersmanagement Falkenhagener Feld West BerlinSpandau [Integrated action and development concept neighbourhood management Falkenhagener Feld West Berlin-Spandau]. Berlin: GeSop $\mathrm{mbH}$. Retrieved from https://falkenhagener-feld-west.de/ ff3010/wp-content/uploads/2019/08/IHEK-FFWest2019-2022-nB-2.pdf

Granger, N. (2013, April 5). Marginalization: The pendulum swings both ways. Unbound. Retrieved from https://www.saybrook.edu/unbound/ marginalization/

Gruber, S., Unterleitner, K., \& Streicher, B. (2010). Grundlegende Charakteristika und Prinzipien für den Dialog Wissenschaft und Gesellschaft [Basic characteristics and principles for the dialogue between science and society]. Vienna: ScienceCenter Netzwerk. https://www.science-center-net.at/wp-content/ uploads/2018/06/Grundlegende-Charakteristikaund-Prinzipien-f\%C3\%BCr-den-Dialog-zwischenWissenschaft-und-Gesellschaft.pdf

Hagay, G., Baram-Tsabari, A., Ametller, J., Cakmakci, G., Lopes, B., Moreira, A., \& Pedrosa-de-Jesus, H. (2013). The generalizability of students' interests in biology across gender, country and religion. Research in Science Education, 43(3), 895-919. https://doi.org/ 
10.1007/s11165-012-9289-y

Hochschild, A. R. (1979). Emotion work, feeling rules, and social structure. American Journal of Sociology, 85(3), 551-575. https://doi.org/10.1086/227049

Kennedy, E. B., Jensen, E. A., \& Verbeke, M. (2017). Preaching to the scientifically converted: Evaluating inclusivity in science festival audiences. International Journal of Science Education, 8(1), 14-21. https:// doi.org/10.1080/21548455.2017.1371356

Kleinginna, P. R., \& Kleinginna, A. M. (1981). A categorized list of emotion definitions, with suggestions for a consensual definition. Motivation and Emotion, 5(4), 345-379. https://doi.org/10.1007/BF00992553

Koch, C., Saner, M., Herrmann, I., Hüsser, A., Schäfer, M., \& Metag, J. (2019). Vertiefungsstudie "Wissenschaftsbarometer": Nutzersegmente von Wissenschaftskommunikation unter der Lupe: eine elektronische, qualitative Tagebuchstudie [In-depth study "science barometer": Examining user segments of science communication under the magnifying glass-An electronic, qualitative diary study]. Zurich: ZHAW Zürcher Hochschule für Angewandte Wissenschaften. https://doi.org/10.21256/zhaw-3164

Kroh, M., \& Fetz, K. (2016). Wie wird der Migrationsstatus in wissenschaftlichen Befragungen erhoben? [How is the migration status determined in scientific surveys?] PPmP-Psychotherapie, Psychosomatik, Medizinische Psychologie, 66(9/10), 410. https://doi.org/10.1055/s-0042-113558

Kuckartz, U. (2016). Qualitative Inhaltsanalyse: Methoden, Praxis, Computerunterstützung [Qualitative content analysis: Methods, practice, computer support]. Weinheim Basel: Beltz Juventa.

Kuhlmann, C. (2008). Bildungsarmut und die soziale "Vererbung" von Ungleichheiten [Educational poverty and the social "inheritance" of inequalities]. In E.-U. Huster, J. Boeckh, \& H. Mogge-Grotjahn (Eds.), Handbuch Armut und Soziale Ausgrenzung [Handbook of poverty and social marginalization] (pp. 301-319). Wiesbaden: VS Verlag für Sozialwissenschaften. https://doi.org/10.1007/978-3-53190906-6_16

Martinez-Conde, S., \& Macknik, S. L. (2017). Opinion: Finding the plot in science storytelling in hopes of enhancing science communication. Proceedings of the National Academy of Sciences, 114(31), 8127-8129. https://doi.org/10.1073/pnas.1711790114

Mayring, P. (2010). Qualitative Inhaltsanalyse: Grundlagen und Techniken [Qualitative content analysis: Basics and techniques] (11th ed.). Weinheim: Beltz.

Mizumachi, E., Matsuda, K., Kano, K., Kawakami, M., \& Kato, K. (2011). Scientists' attitudes toward a dialogue with the public: A study using 'science cafes.' Journal of Science Communication, 10(4), 1-11. https://doi.org/10.22323/2.10040202

Nisbet, M. C., \& Scheufele, D. A. (2009). What's next for science communication? Promising directions and lingering distractions. American Jour- nal of Botany, 96(10), 1767-1778. https://doi.org/ 10.3732/ajb.0900041

Office of Science and Technology, \& Wellcome Trust. (2001). Science and the public: A review of science communication and public attitudes toward science in Britain. Public Understanding of Science, 10(3), 315-330. https://doi.org/10.3109/a036873

Osborne, J., Simon, S., \& Collins, S. (2003). Attitudes towards science: A review of the literature and its implications. International Journal of Science Education, 25(9), 1049-1079. https://doi.org/10.1080/ 0950069032000032199

Otto, H.-U., Ziegler, H., \& Landhäußer, S. (2006). Informelles Lernen in benachteiligten Stadtteilen [Informal learning in disadvantaged urban areas]. In L. Kuppler (Ed.), Orte der Bildung im Stadtteil. Dokumentation des Fachforums der Regiestelle E\&C: Orte der Bildung im Stadtteil 16./17 Juni 2005 in Berlin [Informal learning in disadvantaged city quarters] (pp. 6-10). Berlin: Regiestelle E\&C. Retrieved from https://pub.uni-bielefeld.de/record/1943203

Pandya, R. E. (2012). A framework for engaging diverse communities in citizen science in the US. Frontiers in Ecology and the Environment, 10(6), 314-317. https://doi.org/10.1890/120007

Roeser, S. (2012). Risk communication, public engagement, and climate change: A role for emotions-Risk communication, public engagement, and climate change. Risk Analysis, 32(6), 1033-1040. https://doi. org/10.1111/j.1539-6924.2012.01812.x

Schäfer, M. S., Füchslin, T., Metag, J., Kristiansen, S., \& Rauchfleisch, A. (2018). The different audiences of science communication: A segmentation analysis of the Swiss population's perceptions of science and their information and media use patterns. Public Understanding of Science, 27(7), 836-856. https://doi. org/10.1177/0963662517752886

Scheufele, D. A. (2018). Beyond the choir? The need to understand multiple publics for science. Environmental Communication, 12(8), 1-4. https://doi.org/ 10.1080/17524032.2018.1521543

Scholl, A. (2018). Die Befragung [The survey]. Konstanz: UVK Verlagsgesellschaft $\mathrm{mbH}$.

Schrögel, P., Humm, C., Leßmöllmann, A., Kremer, B., Adler, J., \& Weißkopf, M. (2018). Nicht erreichte Zielgruppen in der Wissenschaftskommunikation: Literatur-Review zu Exklusionsfaktoren und Analyse von Fallbeispielen [Target groups not reached in science communication: Literature review on exclusion factors and analysis of case studies]. Berlin and Karlsruhe: Wissenschaft im Dialog and Karlsruher Institute of Technology. Retrieved from https://wmk.itz.kit.edu/downloads/Zwischenbericht _Wissenschaft_fuer_alle.pdf

Simis, M. J., Madden, H., Cacciatore, M. A., \& Yeo, S. K. (2016). The lure of rationality: Why does the deficit model persist in science communication? Public Understanding of Science, 25(4), 400-414. https://doi. 
org/10.1177/0963662516629749

Smith, N., \& Leiserowitz, A. (2014). The role of emotion in global warming policy support and opposition. Risk Analysis, 34(5), 937-948. https://doi.org/ 10.1111/risa. 12140

Spencer, S. J., Logel, C., \& Davies, P. G. (2016). Stereotype threat. Annual Review of Psychology, 67(1), 415-437. https://doi.org/10.1146/annurevpsych-073115-103235

The Royal Society. (Ed.). (1985). The public understanding of science. London: The Royal Society. Retrieved from https://royalsociety.org/ /media/royal_society_ content/policy/publications/1985/10700.pdf

Thomas, G., \& Durant, J. (1987). Why should we promote the public understanding of science? In M. Shortland (Ed.), Scientific literacy papers (pp. 1-14). Oxford: University of Oxford.

Uslucan, H.-H. (2014). Stereotype, Viktimisierung und Selbstviktimisierung von Muslimen: Wie akkurat sind unsere Bilder über muslimische Migranten [Stereotyping, victimisation and self victimisation of Muslims: How accurate are our images of Muslim migrants]. Wiesbaden: Springer VS.

Valentino, N. A., Brader, T., Groenendyk, E. W., Gregorowicz, K., \& Hutchings, V. L. (2011). Election night's alright for fighting: The role of emotions in political participation. The Journal of Politics, 73(1), 156-170. https://doi.org/10.1017/S00223816
10000939

Valentino, N. A., Gregorowicz, K., \& Groenendyk, E. W. (2009). Efficacy, emotions and the habit of participation. Political Behavior, 31(3), 307-330. https:// doi.org/10.1007/s11109-008-9076-7

Vester, H.-G. (2009). Kompendium der Soziologie I: Grundbegriffe [Compendium of sociology I: Basic concepts]. Wiesbaden: VS Verlag für Sozialwissenschaften.

Wang, M.-T., \& Degol, J. L. (2017). Gender gap in science, technology, engineering, and mathematics (STEM): Current knowledge, implications for practice, policy, and future directions. Educational Psychology Review, 29(1), 119-140. https://doi.org/ 10.1007/s10648-015-9355-x

Watermeyer, B. (2013). Towards a contextual psychology of disablism. London: Routledge.

Wissenschaft im Dialog, \& Kantar Emnid. (2018). Broschüre zum Wissenschaftsbarometer 2018 [Brochure for the science barometer 2018] [Brochure]. Berlin: Wissenschaft im Dialog. https:// www.wissenschaft-im-dialog.de/fileadmin/user_ upload/Projekte/Wissenschaftsbarometer/ Dokumente_18/Downloads_allgemein/Broschuere_ Wissenschaftsbarometer2018_Web.pdf

Wynne, B. (1992). Misunderstood misunderstanding: Social identities and public uptake of science. Public Understanding of Science, 1(3), 281-304. https://doi. org/10.1088/0963-6625/1/3/004

\section{About the Authors}
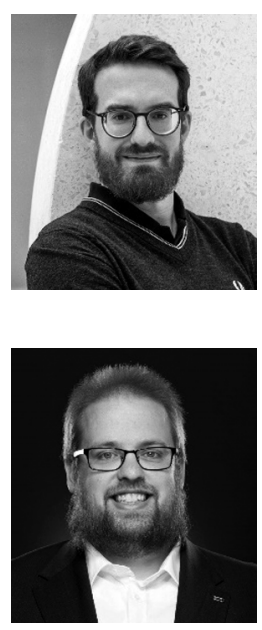

Christian Humm is a Researcher at Karlsruhe Institute of Technology (KIT), Germany. He studied Media Studies and Political Science at the University of Trier, Germany, and the Lancaster University, UK. He works in the project "Science for All" and as a Lecturer at the Department for Science Communication at KIT. His focus lies on the intersections of politics, media, and science communication. He tweets under @cml_net.

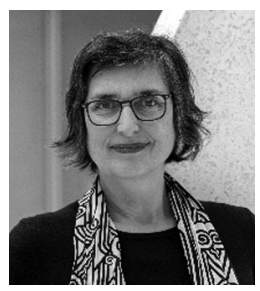

Annette Leßmöllmann (PhD) is a Professor of Science Communication and Linguistics at Karlsruhe Institute of Technology (KIT), Germany. She studied Linguistics, History, and Philosophy at the University of Vienna, Austria, and Humboldt-University, Berlin and earned her PhD in Linguistics at Hamburg University. She worked as a freelance science journalist for the German weekly Die ZEIT, among others. Her research includes digital science journalism, digital discourse on science, neglected audiences, and communication of higher education institutions. She tweets under @annetteless. 